\title{
Urgency of Local Genious Based Spatial Planning Arrangement
}

\author{
Ni Made Jaya Senastri ${ }^{1 *} \quad$ I Nyoman Nurjaya ${ }^{2} \quad$ Sudarsono $^{2} \quad$ Istislam $^{2}$ \\ 1.Doctoral Program of Legal Studies, Faculty of Law, Brawijaya University, Malang \\ 2.Lecturer at Doctoral Program of Legal Studies, Faculty of Law, Universitas Brawijaya, Malang
}

\begin{abstract}
The urgency of regulating spatial planning in rural areas based on local wisdom with the enactment of Law Number 6 Year 2014 on Villages makes an important milestone in the regulation of spatial planning of rural areas based on local wisdom, because in Law Number 26 of 2007, spatial planning is only classified based on national spatial planning, provincial spatial planning, and spatial / district spatial planning, while the spatial planning of village-based rural areas bI haven't thought of it as part of spatial planning.In regulating the authority of spatial planning in rural areas, it should not only be formal legalistic, but must respect the values that live in the community, so that the arrangement of spatial planning in rural areas is useful, effective and provides legal protection, justice and legal certainty.
\end{abstract}

Keywords: Regulations, Spatial Planning in Rural Areas, Local Wisdom

DOI: $10.7176 / \mathrm{JLPG} / 89-17$

Publication date:September $30^{\text {th }} 2019$

\section{Introduction}

After the enactment of Law Number 6 of 2014 concerning Villages (State Gazette of 2014 Number 7, Supplement to State Gazette Number 5495) brought a change that contained new concepts that were in line with Bung Karno's great vision with Tri Sakti, how the future of the village must be seen as a whole not only administratively and geographically, but in terms of social, cultural, economic, legal, political entities. The village should be able to transform into a socially strong, politically sovereign, economically empowered and culturally dignified entity. The substance of Law No. 6 of 2014, actually contains the most obvious alignments for rural people, because there is a new state and village governance that makes the village more sovereign, the relationship between the village and the people is more participatory. This law legally becomes the basis for village regulation including:(1) village position and type; (2) village arrangement; (3) village authority; (4) village administration; (5) rights and obligations of villages and village communities; (6) village regulations; (7) village finances and assets; (8) village and rural area development; (9) BUMDes; (10) village cooperation; (11) traditional villages and (12) guidance and supervision.

One of the scopes of village regulations is the development of villages and rural areas. The dimensions of rural and rural development have a relation to the spatial aspects in rural areas. The meaning of space is common goods or existent that belongs to the public that requires order from the state in terms of their benefit or use by each subject matter, and does not exclude the rights of other subjects (Muchsin \& Koeswahyono 2008). With the enactment of the Village Law, there is actually a need for regulation of spatial planning of rural areas based on local wisdom as a system of national and state living space, as in Law Number 26 of 2007 concerning about Spatial Planning, rural areas are part of district spatial planning where the context of the Unitary State of the Republic of Indonesia that has not been touched is the spatial planning of rural areas based on local wisdom.

Indonesia has many areas which are mostly rural area. The dominance of rural areas in Indonesia is not only shown by the vast area of rural areas, but also by the large population in rural areas nowadays. However, many people tend to misunderstand the rural areas, including the planning experts who are actually more likely to be urban bias that gives their concern more about cities than rural areas. Rural area planning has not been a concern of professional planners for a long time, as if rural areas do not require development planning and spatial planning (Rustiadi 2009).

Developing country rural development expert, Dalal-Clayton concludes that the general issues of rural development in the third world (developing countries) are:

- poverty \& employment problems,

- sustainable management and access to agrarian resources problems, and

- rural-urban linkage problems (spatial \& sectoral links). Rural problems in Indonesia are not much different from Dalal Clayton's general description. Rural areas in Indonesia have a lot of problems, because more than two-thirds of Indonesia's poor are scattered and accommodated in rural areas (Rustiadi 2009).

Juridical aspect of space is a way to formulate spatial planning as a juridical instrument for the utilization of natural resources in an optimal and integrated manner through three main pillars namely the planning, utilization and control stages (Wahid 2016). Spatial planning as a system is listed in Article 1 number 5 of Law Number 26 of 2007 concerning Spatial Planning (State Gazette of the Republic of Indonesia of 2007 Number 68, 
Supplement to State Gazette Number 4725) (hereinafter known as UUPR).

This planning is an important component, and from the legal aspects, this planning can not be separated from the state administration law and state administrative law. Planning is a form of policy, so it can be said that planning is a species of the genus of wisdom (Ridwan \& Sodik 2013). Spatial planning consists of 3 (three) spatial planning, utilization and controlling activities, which are interrelated activities, with the product of spatial planning in the form of a Regional Spatial Planning (Rencana Tata Ruang Wilayah [RTRW]) which hierarchically consists of a National Spatial Plannig (Rencana Tata Ruang Nasional $[R T R W N]$ ), Provincial Spatial Planning (Rencana Tata Ruang Wilayah Provinsi $[R T R W P]$ ), Urban Spatial Planning (Rencana Tata Ruang Wilayah Kabupaten/Kota [RTRWKab/Kota]). And the spatial utilization control is carried out systematically through the establishment of zoning regulations, licensing, granting incentives and disincentives as well as sanctions.

The formulation of the three pillars of space above meets the constitutional classification as an aspect which must be controlled by the state and used for the greatest prosperity of the people, as mandated in Paragraph IV of the Preamble of the 1945 Constitution of the Republic of Indonesia. ${ }^{1}$ One important element in realizing the achievement is to advance general prosperity and develop the nation's intellectual life, so that development must be created by directing the substance of integrated and planned development. Contextually, provisions of Article 33 paragraph (3) of the 1945 Constitution is a constitutional basis for spatial planning. ${ }^{2}$ Therefore, this article can be assumed as an affirmation that, the state can use and utilize the earth, water, and natural resources as much as possible for the prosperity of the people. Therefore the area or territory of the Republic of Indonesia should be utilized effectively in view of the values of the basic conception humans, communities and ecosystems in Indonesia (Ridwan \& Sodik 2013).

\section{Research Methods}

This research is a legal research type. ${ }^{3 "}$ As a know-how activity, legal research is conducted to solve the legal issues at hand".

The approaches that will be used in this research are (Marzuki 2015):

- Statute Approach, in the method of approach to legislation, the researcher needed to understand the hierarchy, and the principles in legislation ${ }^{4}$. So that what is meant as statute is in the form of legislation and regulation or approach using legislation and regulation in analyzing the political synchronization of sustainable regional spatial planning law.

- Historical Approach; this approach was very helpful for the researcher to understand the philosophical rules of law from time to time. In addition to the historical approach, researcher is also able to understand the changes and philosophical developments that underlie a rule of law. By using the historical approach the researcher is also able to examine the development of spatial planning in rural areas in the formation of legislation in the field of spatial planning in Indonesia.

- Conceptual Approach; this conceptual approach should move from the views and doctrines that develop in the science of law, although the concept of law can also be not explicitly found in the law, in order to make it easy to describe, analyze the problems and answer existing legal issues.

\section{Discussion}

\subsection{Legis Ratio Analysis of Spatial Planning in Rural Areas of Act No. 26/2007 on Spatial Planning}

In analyzing the legis ratio of rural area spatial planning arrangements in the Act.No. 26/2007, this study was examined based on philosophical, juridical and sociological foundations. In a statutory regulation, philosophical foundation is legislation has become the consideration or the reason which describes that the regulations that are formed consider life vision, awareness and legal ideals which include the atmosphere of mentality and Indonesian philosophy of life based on Pancasila and the 1945 Constitution. According to Hans Kelsen with his theory "Reine rechtslehre" or "Pure theory of law", it is stated that a new rule of law has a validity if the rule is

\footnotetext{
${ }^{1}$ Text of Alenia IV of the 1945 Constitution:"Then, in order to form an Indonesian Government that protects all Indonesian people and all Indonesian bloodshed and to advance public welfare, educate the nation's life, and participate in carrying out world order based on independence, eternal peace and social justice, Indonesian National Independence has been drawn up. in the Constitution of the Republic of Indonesia, which is formed in the composition of the Republic of Indonesia which is sovereignty of the people based on the Godhead, just and civilized humanity, Indonesian Unity, and Popularism which is led by wisdom in Consultation / Representation as well as by creating a social justice for all Indonesian people ".

${ }^{2}$ Article 33 paragraph (3) confirms that the earth, water and natural resources contained therein are controlled by the state and used for the greatest prosperity of the people ".

${ }^{3}$ Legal research is an activity know-how in law, not just know-about, as quoted in Peter Mahmud Marzuki, Legal Research (Revised Edition, 10th edition), (Jakarta: Prenada Media, 2015), p.60

${ }^{4}$ According to Article 1 number 2 of Law Number 12 of 2011 concerning the Formation of Legislation, legislation is a written regulation that contains generally binding legal norms and is formed or established by a state institution or authorized official through the procedures established in legislation.
} 
based on a higher rule. Thus appears a picture of a legal system as a hierarchical arrangement of legal rules that is a cone-shaped gradation level in the form stufenbau. This arrangement discovered an end point called "Grundnorm" (Kelsen 2008).

Indonesia is a pluralistic society, nation and state in all aspects, including ethnicity, religions, customs, cultures, and so on. This plurality is a reality in the Indonesian community which is undeniable. Such plural conditions can be wisdom and blessings if we are able to connect them in a harmonious cohesion, in order to create beauty and strength. However, pluralism can also be disasters when the mosaic of plurality is not accommodated in its aspirations (Fadjar 2018).

Therefore, Indonesian constitutionalism as a concept that underlies the 1945 Constitution as reflected in the preamble (preamble) offers a constitutional design of the Unitary State of the Republic of Indonesia to create a national state that is democratic in nature and which aims to carry out social justice and humanity. The founders of this Republic believed that it was only through a nationality, democracy, social justice, humanity or human rights that were then combined with the awareness and obedience of the one and only God, which becomes the whole and integrated which is known as Pancasila. The plurality of the nation has a positive purpose (Fadjar 2018).

If the consideration of Law Number 26 Year 2007 is linked to the general explanation of no. 1, it is explained that the territorial space of the Unitary Republic of Indonesia - includes air space, land space, sea space including space on earth - is a resource of God's gift to the Indonesian people that needs to be thankful for, protected, and sustainably managed for the greatest prosperity of the people in accordance with the mandate contained in Article 33 Paragraph (3) of the 1945 Constitution and the meaning contained in the philosophy of the State of Pancasila. Logical consequences of the contents of the number one general explanation, ${ }^{1}$ then the contents of the articles in the spatial planning law constitute are an elaboration of the Pancasila precepts which will guide all spatial planning stakeholders to behave according to the written norms (Koeswahyono 2012).

Legally, Law Number 26 Year 2007 Concerning Spatial Planning (UUPR) which applies as a legal basis for spatial planning since promulgation through its placement in the Republic of Indonesia State Gazette Year 2007 number 68 , is a positive law that must be a reference by all stakeholders in the administration spatial planning in Indonesia.UUPR is a regulation that implements the 1945 Constitution, especially Article 33 Paragraph (3).Like a law, UUPR contains norms that are still general in nature and thus require implementing regulations.

According to Bagir Manan, the function of legislation consists of 2 (two) functions, namely: internal functions and external functions (Redi 2017). Internal functions, this function is more related to the existence of the laws and regulations referred to in the legal system. Internally, the laws and regulations carry out the following functions: the function of law creation; legal renewal function; integration function; legal certainty function. Externally the laws and regulations perform the following functions: change function, stabilization function, convenience function.

Sociologically, Indonesia's development is directed to accelerate the realization of people's welfare through improved services, empowerment, and community participation in development by taking into account the principles of democracy, equity, justice and the uniqueness of an area in the system of the Unitary State of the Republic of Indonesia.Building from the periphery must be understood in a holistic perspective, namely as an affirmation to encourage economic activities that have not been prioritized by the government.Economic activities in the form of territories (rural / border / underdeveloped areas), sectors (agriculture), actors (micro and small businesses). Or the character of (traditional) economic activity.In this connection, development needs to start by laying the foundations of an asymmetrical decentralization policy, namely by implementing a policy of partiality (affirmative policy) to areas that are currently still lagging behind, especially (a) border areas and outermost islands; (b) remote and remote areas; (c) underdeveloped villages; (d) regions whose government capacity is not yet sufficient in providing public services, as described above.Conceptually, the Indonesian builders from the periphery by strengthening regions and villages within the framework of the Unitary State of the Republic of Indonesia (Ministry of National Development Planning/National Development Planning Agency 2015).

\subsection{The Meaning of Sustainable Development in Spatial Planning}

Space can be a basic need for all living things on this earth. With the existence of development activities, the consequences require land and space as a place to carry out development activities. The use of land or space by

\footnotetext{
${ }^{1}$ The territorial space of the Unitary State of the Republic of Indonesia, both as a unitary container that includes land space, sea space and air space, including space in the earth, as well as resources, is a gift from God Almighty to the Indonesian people who need to be thankful for, protected, and managed sustainably for the greatest prosperity of the people in accordance with the mandate contained in Article 33 paragraph (3) of the 1945 Constitution of the Republic of Indonesia, as well as the meaning contained in philosophy and basis Pancasila country.To realize the mandate of Article 33 paragraph (3) of the 1945 Constitution of the Republic of Indonesia, the Law on Spatial Planning states that the state organizes spatial planning, the implementation of its authority carried out by the Government and regional governments while continuing to respect the rights possessed by everyone.
} 
every type of development activity will at least be able to change the environmental setting into a new environmental setting, so that changes in environmental sustainability can occur. This change in environmental sustainability, if not carried out carefully and wisely, will result in a deterioration in the quality and quantity of space.

In general, geographical terms, what is meant by space (space) is the entire surface of the earth which is a layer of the biosphere, where the plants, animals, and humans live. The large earth's surface space, each time the elements can change due to natural processes, can also be caused by changes in human actions. Because the changes are unrelenting, due to natural processes and human actions, it is said that the earth's surface space is dynamic (Jayadinata 1999).

There are several reasons that sustainable development is measured by available land. First, land is limited (finite). According to the note "World Resource Institute" (Jayadinata 1999) the surface area of the earth is 51,000 million hectares and only around 13,000 million hectares are terrestrial. This shows how limited the ability of land to sustain human activity to achieve prosperity. Second, land that supports economic activity illustrates the potential for productivity in the future.

Sustainable development is popularized through reports Our Common Future prepared by the World Commission on Environment and Development (World Commission on Environment and Development) (1987) known as the Bruntland Commission.A statement often quoted by the Bruntland Commission is that sustainable development is development that can meet current needs without compromising the ability of future generations to meet their needs.However, there is a statement that is rarely quoted, namely that sustainable development has two key concepts, namely:1) needs, especially the needs of the poor in developing countries; and 2) limitations of technology and social organization relating to environmental capacity to meet the needs of present and future generations. Thus sustainable development, as interpreted by the Bruntland commission, actually departs from the concept anthropocentric, which makes humans the central theme (Mitchell et al. 2016).

Much effort has been made to develop guidelines and principles for sustainable development.This is with the consideration that without guidelines or principles it is not possible to determine whether a policy or data activity is said to be sustainable, or whether an initiative is consistent with sustainable development.Making guidelines or principles is an interesting challenge, because as realized by the commission, the social and economic system and the ecological conditions of each country are very diverse. So there is no general solution model on which data is created.Each country must develop its own solution model, which is tailored to the context, needs, conditions and opportunities that exist (Mitchell et al. 2016).

\subsection{Spatial Planning, Utilization, and Control}

Based on the understanding of the law there is an understanding that; a) spatial planning is one part of spatial planning activities; other parts are space utilization and control of space utilization; and b) spatial planning produces structural plans and spatial plans. Spatial planning plays a very important role in developing economic, social and environmental benefits, which can be detailed as follows (Djunaedi 2014):

The process of spatial planning generally includes the process of planning, implementing or utilizing spaces that are related to one another.So in spatial planning implies spatial planning.Spatial planning is related to the arrangement of everything in the space as a place for organizing life.Spatial planning is carried out to produce a general spatial plan and a detailed spatial plan.The hierarchical general spatial plan consists of: national spatial plans; provincial spatial planning; and district spatial plans and city spatial plans.

The meaning of planning really depends on the paradigm adopted, according to Davidoff \& Rainer (cited in Hadi 2012) from the perspective of a rational paradigm providing limits on planning as a process for determining the future through a sequence of choices, rational planning is also stated by Dror that planning is a process that prepares.There are some criticisms of the rational planning model, as stated by Flyvberg suggesting that the reaction against rational planning appears in line with the reaction to the undesirable development outcomes caused by an orientation towards economic growth. The participatory, advocacy and radical planning model is a manifestation of the reaction to rational planning (Hadi 2012).

Proponents of the new paradigm of planning such as Bolan and Forester consider that social aspects are important in development planning. They argue that planning is a moral activity.Forester further views that alternative planning theory, leads to an understanding of action or what the planner does rather than just ways to achieve the goal.Through interaction and communication, the planner together with the community helps identify problems, formulate problems, form goals, understand the situation and identify solutions to how to solve the problems in question.Valid and useful knowledge about human behavior also includes internal values, tastes and judgments as they act and behave.In this context planning is a moral activity, planners are communicators who use simple language in their work to make logic out of human behavior (Hadi 2012). 
3.4 Legal Implications of the Arrangement of Authority for Spatial Planning in Rural Areas in Law Number 6 Year 2014 Regarding Villages

The Indonesian state is divided into regions consisting of provinces and regency / city regions. While the village is domiciled and is within the district / city area. When viewed in terms of government, there are Government, Provincial Government, Regency / City Government and Village Government.If this is the case with the regions, the regions must also give freedom with the autonomy they have to the villages.Is not the existence of the village seen from an economic, sociological, juridical, political, and historical perspective, in essence the village is a real form, democratic, autonomous with traditions, customs and laws themselves are very deeply rooted, and relatively independent from interference from external power entities (Dwipayana 2003). Based on the framework of constitutionalism, namely government based on the constitution which includes the conception that structurally, the power of authority of state organizations in regulating government only reaches the subdistrict level (Atmadja 2008). The existence of a village government is independent, the village government has autonomy that has the right to regulate and take care of the interests of its people.

Law No. 6 of 2014 provides great opportunities to regulate development planning based on the primary needs of rural communities without being burdened by programs of various government agencies, hereinafter referred to as 'village autonomy'. Village autonomy is genuine, round and complete autonomy and is not a gift from the government. Instead the government is obliged to respect the original autonomy held by the village (Widjaja 2008).

There are 4 (four) important things to understand about village autonomy, viz First, formal legal perspective which refers to the dictums stipulated in the Law that "the village is a legal community unit that regulates and manages its own household".Here the village as a legal subject has the right and authority to make legal actions, make binding regulations, control the land, make official documents, deal with the court, organize cooperation, and others.However, villages as autonomous regions cannot only be seen as legal subjects, but also become part and implications of decentralization so that they can not only be seen from the legal side but also in terms of the relationship between the village and the state.Therefore, the village is also entitled to get the distribution of authority not only in terms of government management, but also financial management.Second, a village can be said to be autonomous if it is recognized by the state of its existence along with its original rights and customs.Here the state not only recognizes its existence, but also protects and provides the distribution of power, authority in the management of government and finance.Third, by combining functions self governing community (legal community unity) with local self government necessary structuring of customary law community units that are part of the village territory into villages and traditional villages. The functions and duties of the two are almost the same, but differ in the implementation of original rights, especially those relating to social preservation, territorial regulation, order and order of indigenous and tribal peoples, and the implementation arrangements on the basis of the original arrangement. The existence of villages and traditional villages received the same treatment from the Government and Local Government (Regional Government).Therefore, there will be a separate regulation regarding this matter regulated in Law No.6 of 2014.Fourth, through Law No. 6 of 2014 given a broad range of space to regulate development planning based on the priority needs of rural communities without being burdened by work programs from various government agencies, hereinafter referred to as 'village autonomy' as genuine, round and complete autonomy and is not a gift from the government (Widjaja 2008).

The enactment of the Village Law, which affirms the authority of the village government in preparing plans and managing development at the local scale of the village, naturally positions the planning process as a significant part of development planning.How far the village spatial planning position is justified while the Spatial Planning Law does not regulate the authority of the village government to make spatial planning within the village scope. This has become increasingly unclear because on the other hand the Village Law also does not explicitly and in detail how village spatial planning is regulated.In the Spatial Planning Law, spatial plans based on administrative regions only recognize 3 categories, namely, National Spatial Planning (RTRWN), Provincial (Provincial RTRW), Regency (Regency RTRW) or City (City RTRW).The term relating to the village is only found in the phrase space of rural areas as stipulated in Article 5 paragraph (4) "Spatial planning based on regional activities consists of spatial planning of urban areas and spatial planning of rural areas".In other words, the term rural is only seen as a spatial entity based on regional activities.In the process of determining rural areas is a meeting of the planning process top-down and bottomup, where the regent / mayor can directly determine the determination of rural areas with the approval of the village heads whose villages belong to the area to be determined, as well as the reverse process, the village heads who agree to propose their village into one area to the district head / mayor to be designated as a rural area.This is where the context of village spatial planning if related to the context of rural area planning becomes significant, where villages have prepared themselves in the spatial planning process through initiation bottom up planning. 


\section{Conclusion}

The urgency of regulating spatial planning in rural areas based on local wisdom after the enactment of Law Number 6 of 2014 concerning Villages is due to several factors, namely:

- Village-based spatial planning of rural areas has not been thought of as part of the national spatial planning system.

- The regulation of spatial planning authority in rural areas which is only formal in nature is legalistic but must respect the values that live in the community.

- The paradigm of spatial planning in rural areas still uses the Top-down Bottom-Up paradigm, and has not used the bottom-up paradigm based on local wisdom as the basis for spatial planning.

- The arrangement of spatial planning in rural areas has the aim of creating prosperity and protection of resources so that they are efficient, effective, and provide legal protection, justice and legal certainty.

\section{References}

Atmadja, I D. G. (2008). 'Awig-Awig Desa Adat Bali: Suatu Analisis Hukum Tata Negara (Awig-Awig of Traditional Village of Bali: An Analysis of State Administration Law)'. Dinamika Perkembangan Hukum Tata Negara dan Hukum Lingkungan (The Dynamics of Development of State Administration Law and Environmental Law). Special Edition Collection of Essays in commemoration of the retirement of Prof. Dr. Siti Sundari Rangkuti, S.H. Surabaya: Airlangga University Press.

Djunaedi, A. (2014). Pengantar Perencanaan Wilayah dan Kota (Introduction to Regional and City Planning). Yogyakarta: Gadjah Mada University Press.

Dwipayana, A. (2003). Pembaharuan Desa Secara Partisipatif (Participatory Village Renewal). Yogyakarta: Pustaka Pelajar.

Fadjar, M. A. (2018). Menuju Negara Bermartabat: Independensi, Etika Pejabat Publik, dan Hukum Berkeadilan (Towards a Dignified Country: Independence, Ethics of Public Officials, and Fair Law). Malang: Intrans Publishing.

Hadi, S. P. (2012). Dimensi Lingkungan Perencanaan Pembangunan (Environmental Dimensions of the Development Planning). Yogyakarta: Gadjah Mada University Press.

Jayadinata, J. T. (1999). Tata Guna Tanah dalam Perencanaan Pedesaan, Perkotaan dan Wilayah (Land Use in Urban \& Regional Rural Planning). $3^{\text {rd }}$ edn. Bandung: ITB Bandung Publisher.

Kelsen, H. (2008). Teori Hukum Murni: Dasar-Dasar Ilmu Hukum Normatif (Pure Theory of Law). Translated from German by Muttaqien. Bandung: Nusa Media.

Koeswahyono, I. (2012). Hukum Penatagunaan Tanah dan Penataan Ruang di Indonesia (Problematika antara Teks dan Konteks) (Law on Land Management and Spatial Planning in Indonesia (Problems between Text and Context)). Malang: UB Press.

Marzuki, P. T. (2015). Penelitian Hukum (Legal Research). 10 $0^{\text {th }}$ edn. Jakarta: Prenada Media.

Ministry of National Development Planning/National Development Planning Agency. (2015). Attachment of Republic of Indonesia Presidential Regulation Number 2 Year 2015 Regarding 2015-2019 National Medium-Term Development Plan (RPJMN), Book III of Regional Development Agenda. Ministry of National Development Planning, National Development Planning Agency, Jakarta.

Mitchell, B., Setiawan, B., \& Rahmi, D. H. (2016). Pengelolaan Sumberdaya dan Lingkungan (Resource and Environmental Management). Yogyakarta: Gadjah Mada University Press.

Muchsin, H. \& Koeswahyono, I. (2008). Aspek Kebijaksanaan Hukum Penatagunaan Tanah dan Penataan Ruang (Legal Aspects of Land Administration and Spatial Planning). Jakarta: Sinar Grafika.

Redi, A. (2017), 'The Science and Legislation Theory Module', Legal Drafting Education and Training. Faculty of Law, Universitas Tarumanagara, Jakarta.

Ridwan, J. H. \& Sodik, A. (2013). Hukum Tata Ruang dalam Konsep Kebijakan Otonomi Daerah (Spatial Law in the Concept of Regional Autonomy Policy). Bandung: Nuance.

Rustiadi, E. (2009). 'Penataan Ruang Kawasan Perdesaan dan Agropolitan Sebagai Strategi Pembangunan Perdesaan (Spatial Planning for Rural and Agropolitan Areas as a Rural Development Strategy)', Spatial Online Bulletin ISSN: 1978-1571 (July-August edition).

Wahid, A. M. Y. (2016). Pengantar Hukum Tata Ruang (Introduction to Spatial Law). Jakarta: Predana Media.

Widjaja, HAW. (2008). Otonomi Desa: Merupakan Otonomi yang Asli, Bulat dan Utuh (Village Autonomy: Original, Round, and Intact Autonomy). Jakarta: PT. Raja Grafindo Persada. 